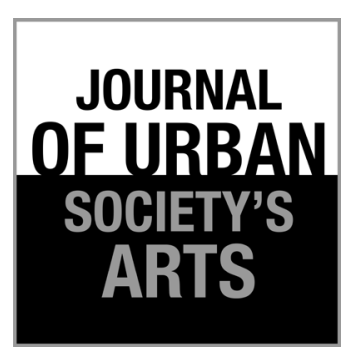

Volume 8 Number 1, April 2021: 15-27

\section{Sindhenan Banyumasan: An Example of Variation and Pluralism of the Javanese Female Singing Tradition}

\section{Ilaria Meloni}

Ethnomusicology, Faculty of Literature and Philosophy, Department of Greek-Latin and Italian Studies, Music and Performing Arts, La Sapienza University of Rome Via Aldo Moro 5, 00185 Rome (Italy)

(+39) 06 49911, presidenzalettere@uniroma1.it

Email: ilaria.meloni89@gmail.com; HP.: +393801533615

\begin{abstract}
Sindhenan Banyumasan, meaning the female traditional Javanese singing in the style of Banyumas, represents an interesting "regional variant" of sindhen vocal tradition. Flourished in the court of Surakarta in the 19th century, the sindhen practice has spread rapidly across the centuries, reaching many territories outside the court centers. Deeply connected with the ancient practices of the singer dancers, sindhen styles are still indicative of the local traditions and a testimony of differences and continuity with the formal teaching of central Javanese institutions. Despite the importance of the local variants, existing international studies on sindhenan have mainly focused on the styles of Yogyakarta and Surakarta, often neglecting rural areas, like Banyumas. The aim of this paper is to shed some light on sindhen practice in Banyumas territory, investigating its history, performance practice, repertoires and vocal style. Research outcomes reveal how Banyumas singing tradition has many common traits with Yogyakarta and Surakarta vocal practices, though it maintains some specificities, index of the pluralism of Javanese music and performing arts.
\end{abstract}

Keywords: sindhenan; Banyumas; musical pluralism

\begin{abstract}
ABSTRAK
Sindhenan Banyumasan: Salah Satu Contoh Variasi dan Pluralisme dalam Tradisi Vokal Wanita di Jawa. Sindhenan Banyumasan, memiliki pengertian yaitu nyanyian atau praktik vokal tradisional wanita Jawa dalam gaya banyumas, yang mewakili "varian regional” yang menarik dari tradisi vokal sindhen. Berkembang di keraton Surakarta pada abad ke-19, praktik sindhen telah menyebar dengan cepat selama berabad-abad, menjangkau banyak wilayah di luar pusat Kerajaan (Kraton). Gaya Shindenan, yang masih sangat terkait dengan praktik konservatif dari para seniman penari dan penyanyi tradisional, masih menunjukkan tradisi lokal dan kesaksian tentang perbedaan dan kesinambungan pengajaran formal pada institusi-institusi di Jawa Tengah. Terlepas dari pentingnya varian lokal, terdapat studi internasional tentang sindhenan yang terutama lebih sering fokus dalam membahas gaya Yogyakarta dan Surakarta, dan seringkali mengabaikan daerah pedesaan, seperti Banyumas. Tujuan dari tulisan ini adalah untuk menjelaskan praktik sindhen di wilayah Banyumas, dan menelusuri sejarahnya, praktek pertunjukannya, repertoar, dan gaya vokal. Hasil dari penelitian ini mengungkapkan bagaimana tradisi sindhenan Banyumas memiliki banyak kesamaan dengan praktik vokal (sindhenan) gaya Yogyakarta dan Surakarta, meskipun hal tersebut tetap mempertahankan beberapa kekhususan, serta indeks kemajemukan musik dan seni pertunjukan Jawa.
\end{abstract}

Kata kunci: sindhenan; Banyumas; pluralisme musikal 


\section{Introduction}

Sindhenan (traditional female singing) is one of the most widespread vocal traditions in Java. However, amongst the consistent production of studies on gamelan music, this practice seems to have not been devoted the attention it deserves. Central Javanese sindhenan can count on a discrete though not exhaustive bibliography (mostly for what concerns Surakarta and Yogyakarta styles, see (Walton, 1996); (Cooper, 2000); (Sutton, 1984); (Weintraub 2004). On the contrary, almost nothing can be found about sindhenan practice in other "regional styles" or local variants. Excepts for the studies of Van Zanten (1989) in Sundanese area and those of Rahayu (2017) in East Java, we currently have no mention of the female singing tradition in areas far from the central Javanese courtly centres. Particularly, the sindhen practice in Banyumas Regency (Central-West Java) known as sindhenan banyumasan, has still many undisclosed aspects that need to be unearthed. Amongst others, (Sutton, 1986) made a significant contribution to the study of "musical pluralism" in Javanese gamelan music. He has compared diverse gamelan musical styles including those of Yogyakarta, Surakarta, Banyumas, Semarang and East Java (SurabayaMojokerto). Also, he discussed the meaning of "authenticity" in music and the role of cultural politics in the development of regional styles, in continuity and contrast with the central Javanese style taught in the most renowned conservatories (ISI Yogyakarta and ISI Surakarta). Specific to Banyumas area, significant international studies are those of Sutton $(1985,1986,1991)$ and Lysloff (1990, 1992, 1993, 2001, 2009). Other relevant works by Indonesian scholars are those of Yusmanto (2006) and Herusatoto (2008). On sindhenan banyumasan practice we find some interesting papers by Muriah Budiarti (2008; 2013), sindhen and vocal teacher at ISI (Institut Seni Indonesia) Surakarta.

Considering that Banyumas Regency is located in a liminal territory, between central Java and Sunda, it is clear how its music and performance practice are exposed to many diverse influences coming from the neighbouring territories. However, Banyumas is a cultural area preserving its own specificity and traditions. Arts that are highly distinctive of Banyumas style are for example: wayang jemblung (Rene T. A. Lysloff, 1990), lènggèr (René T.A. Lysloff, 2002) and calung (Lysloff 1992). The vast majority studies seem to agree on the vibrant and lively character of Banyumas music, its inclination to humour and parody, and its "popular" (rakyat) nature opposed to some extent to the court aesthetic. How can these elements be detected in the vocal practice and how does the latest differ from Yogyanese and Solonese styles? But, most important, what does Banyumas vocal tradition represents in the framework of Javanese music?

\section{Methodology}

I conducted the research on sindhenan banyumasan adopting the participant observation methodology (Solís, 2004) (Rice 2014) or practiceled research (Dean \& Smith 2009; Penny 2014). In 2017, I spent several months in Banyumas, in Pegalongan village, hosted by Mak Narsih (Narsihati) and Pak Chedi (Suchedi), owners of the Sanggar Seni Budaya Ngudi Luwesing Salira. On December the $12^{\text {th }}, 2017$, at 6 p.m., I arrived in Purwokerto station, the administrative province of Banyumas Regency. Outside the station, waiting for me, there were Mak Narsih and her family ready to give me a warm welcoming and to bring me to their village and into their lives. Two hours later, I was already joining one of the weekly rehearsals with the calung music group, inhered by local sindhen and lénggér dancers. Mak Narsih, a charismatic woman, elegantly dressed with fine jewels and hair ornaments (a legacy of her long and honoured career of singer-dancer) offered me to become a teacher and a mentor. She was excited to have an "Italian sindhen" to train. It was an opportunity to disseminate Banyumas music knowledge worldwide and to share her experience of being a sindhen and lènggèr dancer in tempo doeloe ("old times").

Over the period I spent in Banyumas, I often joined in rehearsals and performances, alternating active participation in the guise of sindhen and 
audio-visual documentation (using a Tascam DR40 and a Sony Handicam HDR-CX625). To combine multiple activities (learning, performing and documenting) was determinant in order to master the vocal practice and to be able to achieve a double perspective (both "emic" and "etic", Bartz \& Cooley 1997). The direct involvement of the Pegalongan music community in my research activity was also determinant to obtain updated information on the performances and to gain the co-operation of artists and musicians who invited me to their houses for showing me local traditions, some of those very rare (like buncis and bongkel). ${ }^{1}$

After completing my fieldwork in Banyumas, I decided to conduct a brief survey in ISI Surakarta, where I joined several classes of karawitan Banyumas with Pak Darno and Ibu Muriah, in order to have a meter of comparison.

Once I came back to Italy (my home country), I revised and selected the audio-visual material and the fieldnotes. I translated interviews from Indonesian to English and I transcribed music recordings in kepatihan notation. Further, I analysed data, comparing the music analysis with the ethnographic information, in order to establish connections and drive conclusions, also basing on my previous experience as sindhen and researcher in Yogyakarta (2014-2016).

\section{Results and Discussion}

Participant observation and existing literature helped to disclose many aspects of the sindhen activity in Banyumas, their music repertoire and vocal style. Before discussing the current research findings, it is necessary to offer an historical overview on female singers and singer-dancers.

\section{Singers and Singer-Dancers}

The sindhen tradition in Banyumas is strictly connected with the ancient practice of itinerant singer-dancers, known under different terminologies according to the geographic and cultural distribution on the Javanese territory: ronggeng and ketuk tilu in West Java, tayub in central-East Java and gandrung in Banyuwangi (Yampolski 1991). Some of these practices have undergone a slow decline, especially during Suharto regime (Vickers 2005), while others have gone through processes of epuration and revival (it's the case of ronggeng and ketuk tilu, now converged in jaipongan, Baier \& Manuel 1986, Saedipun 2015 ). In Banyumas, singer-dancers are called lènggèr, and the practice is still alive nowadays, though there are noticeable differences with the past. In the beginning, lènggèr was held in occasion of public and private celebrations such as births, marriages and circumcisions. The writer Ahmad Tohari (2012) described many ritual and social aspects of lènggèr in his best-seller Sang Penari ("The Dancer"). Singer-dancers of the past were believed to be the incarnation of Dewi Sri, the rice goddess (or the Indonesian Mother Earth) so they were considered a precious "property" for a village and its inhabitants. Music and performance were powerful tools to summon the goddess in order to guarantee prosperity and crops abundance. During colonial times, lènggèr became the itinerant practice of female singer-dancers performing for money, accompanied by a small music ensemble and two comedians (badhut). Members of the audience (often males) were involved in social dances and were used to offer a tip (sawer) to request songs or dance turns with the singer-dancer. Often, the requests might contain lascivious implications. For these reasons, lènggèr went through an epuration campaign during the New Order and appears nowadays in a more polite and standardized form. According to Lysloff (2001: 1), in the times of New Order, it was already possible to assist to lènggèr performances in the purged, "respectful and disciplined" (sopan dan rapi) form.

The female performer of the past was thus both a singer and a dancer. Nowadays, these two roles appear separated. The scission of vocal and dancing skills didn't happen only in Banyumas. According to Sutton (1984), already in the $19^{\text {th }}$ century, female singer-dancers were hired in the courts of Surakarta

1 Buncis (literally "green beans"), is an ancient trance dance accompanied by rattle bamboo instruments. Bongkel is another form of bamboo rattle music, usually played by a small ensemble and a singer. 
and Yogyakarta, though in a different guise: some of those women were transformed in refined bedhaya and srimpi dancers (Di Bernardi 1995; HughesFreeland 2008) while others, trained in the vocal practice with court gamelan orchestras (Surtihadi 2014), became sindhen. The disjunction of singing and dancing was determinant in order to elevate the figure of the lascivious, terrain singer-dancer of the past in favor of the establishment of a new "refined" (halus) female performer, in accordance to court aesthetics. While, in central Java, sindhen can still be identified with the court ideal of the "heavenly nymph" (Walton 1996), in Banyumas they preserve a stronger connection with their ancestors. During my fieldwork in Banyumas, I encountered both sindhen and singer-dancers, though the latest were present on a minor degree. In fact, according to Mak Narsih, less and less young girls are capable to learn both singing and dancing and to perform them altogether, as in the past. In many cases, I witnessed lènggèr dancers accompanied by the sound of calung (bamboo ensemble) complemented by an ordinated row of sindhen executing banyumasan music pieces (Ricik Ricik, Sekar Gadung, Ilho Gondhang), sitting and behaving like the central Javanese colleagues.

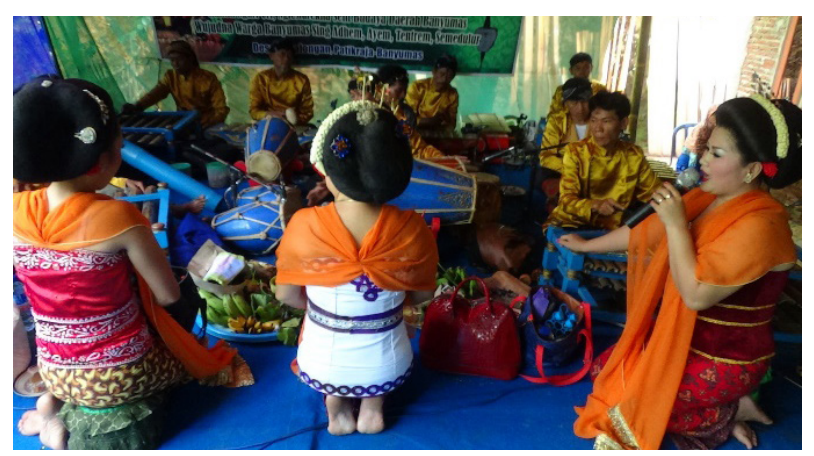

Figure 1. Singer-dancers in a lènggèr performance (Baturaden, June $21^{\text {st }}, 2018$, photo by Ilaria Meloni).

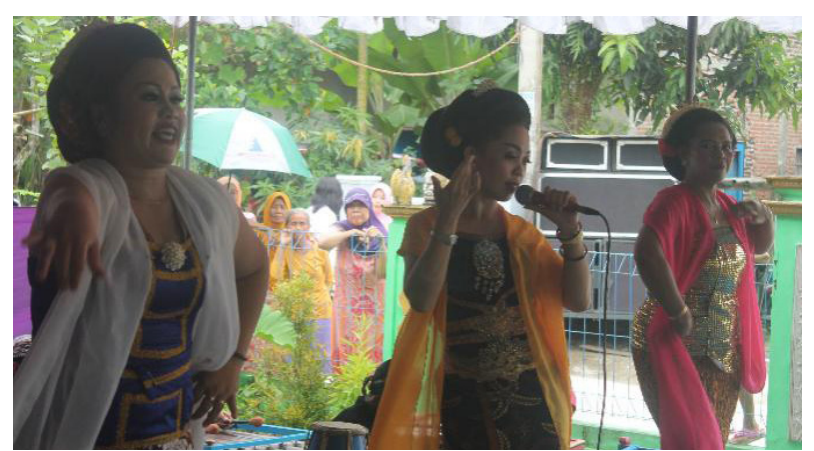

Figure 2. Singer-dancers in a lènggèr performance (Banyumas, Sanggar Seni Budaya Ngudi Luwesing Salira, January 13 ${ }^{\text {rd }}$, 2018, photo by Ilaria Meloni).
In Banyumas, sindhen do not only join in calung and lènggèr performances but they also partook in ebeg (the local version of hobby-horse trance dance), kenthongan (bamboo and drums modern ensembles) and rarer genres as buncis (trance dance), sintren (trance dance) and bongkelan (small bamboo, drums and voice ensembles).

They also assume a significant role in wayang kulit (shadow puppet theatre) of Banyumas, which is more and more similar to the Yogyanese and Solonese one. However, the banyumasan style is still manifest in some present-day wayang kulit. In these cases, lènggèr dance is still carried out before the beginning of the performance and in some minor scenes (like the perang kembang). Expert sindhen accompany the dance singing the pieces of banyumasan repertoire, remaining kneeled on the right side of the puppeteer.

Thanks to Mak Narsih accounts, I could draw an evolving framework showing how sindhen and singer-dancers in Banyumas have shaped their beings and cohabited over the last decades. Mak Narsih constitutes a remarkable example. She was born on December 31 $31^{\text {st }}$ 1965, in Banyumas and she is still renown in the regency as one of the most famous sindhen and lénggér dancers (for this reason, she

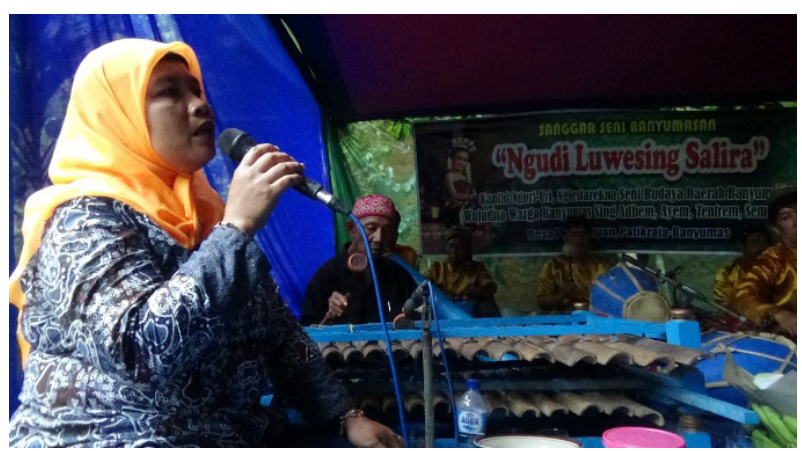

Figure 3. Sindhen in a lènggèr performance (Baturaden, June $21^{\text {st }}, 2018$, photo by Ilaria Meloni).

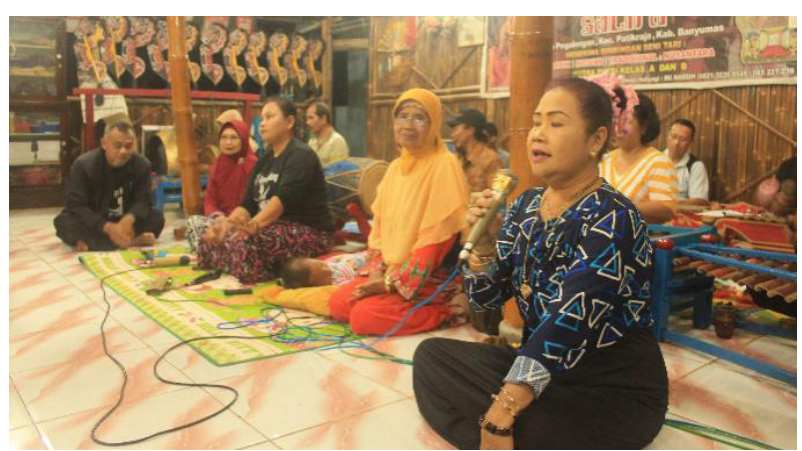

Figure 4. Mak Narsih and the other sindhen of Sanggar Seni Budaya Ngudi Luwesing Salira during a calung rehearsal (Banyumas, December $15^{\text {th }}, 2017$, photo by Ilaria Meloni). 
is often called "maestro lènggèr"). She started her career in a very young age, learning alami (via aural transmission, or "naturally") and measuring her skills directly on stage. She became a very popular artist during the years of Suharto. Mak Narsih still lives in the village of Pegalongan with her husband, Pak Suchedi, a calung player and a teacher in the local SMA (Medium High School). Mak Narsih house stands right in front of the recently built sanggar, inaugurated in 2014 thanks to the contribution of Pegalongan inhabitants. The sanggar is a great resource for Mak Narsih and Pegalongan artistic community. At present, lènggèr troupes don't perform very often like in the past. Therefore, to own an artistic space allows experienced artists to teach the children of the village and to train future musicians, dancers and sindhen, transmitting a kind of knowledge which is rarely taught in conservatories. Every day, after returning home back from school, Pak Chedi takes care of the sanggar and prepares the material for the rehearsals and the calung music sessions. This place has constituted my daily routine over the months during which I intensively practiced sindhenan banyumasan with Mak Narsih and the musicians of the calung group. Giving the close relation I achieved with Mak Narish, I decided that I wouldn't conduct a formal interview with her, because I didn't want to make her uncomfortable. Instead, I asked if I could turn on my Tascam recorder during our daily lessons, in the quiet atmosphere of the sanggar. Between a teaching and the other, Mak Narsih used to narrates her experience of singer-dancer:

I became a lènggèr when I was seven years old. I didn't know yet how to dance. I was pushed to go on stage and I just kept imitating the

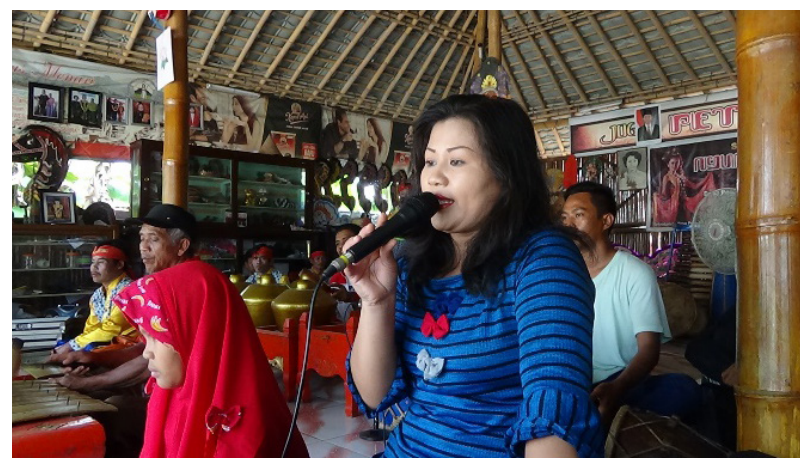

Figure 5. Sindhen in a ebeg performance (Banyumas, Sanggar Seni Budaya Ngudi Luwesing Salira, June $18^{\text {th }}, 2018$, photo by Ilaria Meloni). other dancers. I didn't know how, but my body started to move with the music. People say I have the indang [the gift] (personal communication of December $\left.15^{\text {th }}, 2017\right)$.

It is common for lénggér dancers to start their training while still very young. In Pegalongan village, Mak Narsih trains a group of little girls who attend classes at the sanggar every weekend. Dance is trained separately from the singing, even though, according to Mak Narsih, a true Banyumas female artist should be able to sing and dance at the same time, like in the old lènggèr tradition. However, in the current practice is more and more common to see a row of sindhen sitting steady along the stage, accompanying mute dancers busy in lènggèr choreographic movements. Mak Narsih received the indang (the "gift" or vocation), which is rare amongst the new generations.

\section{Education and Training}

Nowadays, many young girls prefer to receive a formal education to SMKI (music high school) and music academies of Yogyakarta and Surakarta. A formal education is not only considered to guarantee

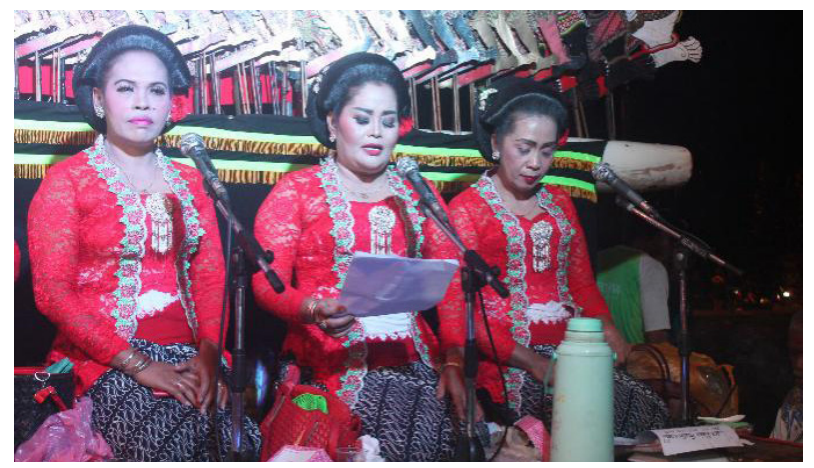

Figure 6. Sindhen in a wayang kulit performance (Banyumas, December $23^{\text {rd }}, 2017$, photo by Ilaria Meloni).

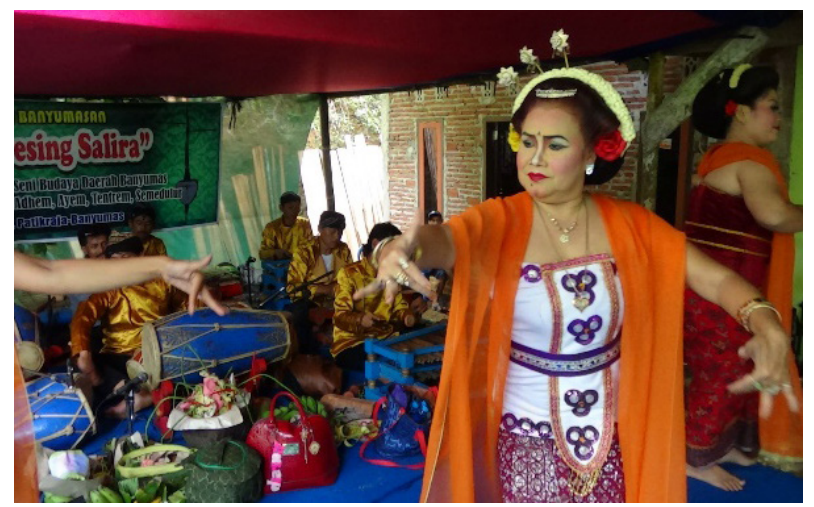

Figure 7. Mak Narsih in a lènggèr performance (Baturaden, June $21^{\text {st }}$, 2018, photo by Ilaria Meloni). 
more solid basis for early careers but also to give prestige and offer good job opportunities. Notwithstanding, sindhen trained in central Javanese conservatories often risk to lose their own cultural background in favor of a more standardized knowledge transmission, modelled on the music practice of the court centers. In many cases, sindhen coming from Banyumas end up to practice their native music style jointly to that of Surakarta or Yogyakarta, the first in the form of music dareah ("territorial music") or regional variant. The implications are many, as noticed by Sutton:

The offering of formal classes in what have generally been seen as "folk arts", of course, tends to change the conception of those arts. The very fact that students get credit towards a diploma by learning to play calung, for example, raises the stature of the calung genre. Moreover, the methods of teaching contribute toward a new conception of Banyumas music. Notation is pervasive. Blackboards and notebooks are full of the ciphers representing basic instrumental melodies for Banyumas pieces, and personal variants become inconsistencies, to be discouraged (Sutton 1986: 125).

I experienced both the alami, "natural" and akademi "academic" teaching methodologies, the first with Mak Narsih in Pegalongan village and the second with Ibu Muriah at ISI Surakarta. Classes with Mak Narsih were based on listening and imitation, without written notation. Once I had memorized a good number of cengkok (melodic patterns) and parikan (free-metered rhymes) I was ready to train new learnings directly on stage (in calungan, wayang or lènggèr performances). After few months I was able to sing the masterpieces of Banyumas tradition like Ricik Ricik, Sekar Gadung, Bendrong Kulon and Eling Eling and to create my own cengkok and parikan banyumasan without reading any notation. I even created my own parikan rhyme, reciting: "Baturaden, Karangpule, nyawang sindhen sing wong bule". Meaning: "Baturaden [locality], Karangpule [village], we are watching a foreign sindhen". To Mak Narsih, the real training was in performance. There, I could really challenge myself and, also, I could imitate other singers and learn through practice.
In May 2018, I joined several classes of karawitan banyumas (Banyumas traditional music) in ISI Surakarta. Guided by Pak Darno and Ibu Muriah, I could study banyumasan repertoire with a different methodology and I could discuss with my teachers about relevant aspects of Banyumas vocal practice. Ibu Muriah constitutes an excellent example of a sindhen who received a double formation ("natural" and "academic"):

I started practicing sindhenan at primary school, in a natural way. My father had a music group called Dwija Laras so I used to partake in rehearsals. Then, my uncle discovered that I had a good voice and suggested me to go to study to Purbalingga (interview of May $24^{\text {th }}, 2018$ ).

The first vocal education of Ibu Muriah is aural, due to her artistic family descendance. Her first approach to Javanese music is from a "local" perspective, within Banyumas art context. Only at a later stage, Ibu Muriah is introduced to the use of written notation and to the Solonese style karawitan. The musicians of her first music group used to learn "by ear" (menguru kuping), in the same way that I experienced with Mak Narsih in Pegalongan village. Ibu Muriah discovered the Solonese karawitan thanks to the RRI (Radio Republik Indonesia) broadcastings. The radio, together with cassette recordings, has been a powerful media during the 50's and the 60's and it played a determinant role in the diffusion of "regional styles" (Lockard 1998: 84) which led to a widespread musical pluralism in the following decades. However, not all the "regional styles" could benefit of an equal distribution via mediatic channels. The style of Javanese cultural centers (mainly Surakarta) was often presented as an example of excellence, so it became a standard model to imitate. According to Ibu Muriah:

During the 70's, the bedrock of karawitan music were the styles of Yogyakarta and Surakarta. My uncle introduced me to the classical gendhing (Wilujeng, Puspowarna) so I started focusing on that repertoire. I kept practicing banyumasan pieces only in the spare time (interview of May $24^{\text {th }}, 2018$ ).

From the 70's, Yogyakarta and Surakarta styles started to be taught as major subjects in karawitan 
studies even in conservatories and music academies, while other local traditions were acknowledged as subsidiary classes, often placed in etnomusikologi (ethnomusicology) department. Musical pluralism has started to be more and more encouraged between the ' 80 s and the '90s. Students from diverse areas crossed their paths in the main music institutions and became able to improve their own creativity and to open the way to possible collaborations. Ibu Muriah enrolled in ISI Surakarta in 1982 and there she founds a fertile ground to cultivate her "bi-musicality" (Hood 1960):

At ISI Surakarta, there were sindhen from all over Javanese island. They taught me many other styles: Sunda, Banyuwangi, Semarang, Madura and many others. Formerly I enrolled in etnomusikologi, then I also undertook Solonese style karawitan, so now I teach both (interview of May 24 ${ }^{\text {th }}, 2018$ ).

Ibu Muriah acknowledges her "bi-musicality" as an enrichment other than a way to offer diversified perspectives and multiple approaches to her students.

In Pak Darno and Ibu Muriah classes, students use to learn with the aid of written notation that they find on apposite manuals. Students follow the scored notation for playing both balungan (skeleton melody) and sindhenan vocal parts. Ibu Muriah guided me in the execution of the piece Ricik Ricik showing me the written cengkok and adding some new ones which she wrote herself on the page, offering me more variation possibilities but still remaining faithful to the score. She made a calibrated use of both oral and written methods and adopted a critical approach, explaining me the musical history of the musical piece from the original version to the later additions by Ki Nartosabdo and Pak Rasito. Many gendhing banyumasan seems to have undergone the same manipulation over the past decades. The structure of the pieces and their playful spirit makes them particularly suitable for innovations, especially in the vocal elaboration.

\section{Repertoire}

According to Sutton, the whole of traditional compositions in Banyumas style (gendhing banyumasan) it's a:
[...] Small corpus of the traditional repertory (only about 50-60 pieces), the preference for "small" formal structures (pieces with short melodic phrases), and the limitation of this repertory to only two pathet (modes) within one laras (scale system). All traditional Banyumas pieces are in the five-tone laras slendro, pathet sanga or manyura (1986: 126).

While the central Javanese repertoire is very wide, so that many musicians say that it's nearly impossible to memorize all the melodies over a life-time, the repertoire of gendhing banyumasan is more restricted and usually expert musicians manage to master good number of pieces in a short time. Differently from the classical gendhing (which can count 8 to 256 beats per gong cycle), the most common form for the gendhing banyumasan is lancaran (an 8 beat per gong cycle structure). However, the limited corpus and the less complex musical structure led Banyumas musicians, teachers and composers to challenge their creativity with increasingly innovative solutions:

Musicians at SMKI Banyumas have begun to counter some of the limits in several ways. Some compose pieces in the seven-tone pelog system, and one of the most prolific is Rasito, one of the top music teachers at SMKI. While new compositions consist primarily of short melodic phrases, the use of pelog expands the sound resources of Banyumas tradition considerably (Sutton 1986: 126).

Variety in music elaboration (garapan) is undoubtedly a peculiarity and a strength of Banyumas music. For instance, in Yogyakarta and Surakarta practice, lancaran is often executed in a loud-playing style, in the first irama (tempo), mainly in the instrumental rendition with a lagu or koor (unison vocal melody or choral section), rarely with sindhenan improvisation. Lancaran are often used to mark transitions between a piece and another in wayang theatre, or function as ending pieces in klenengan (music sessions). They seem also to be the most suitable music forms to introduce new students in the basics of gamelan practice. In Banyumas, instead, lancaran form can be played according to several garapan (elaborations) in which sindhen voices play a pivotal role and they are needed to accompany a wide range of performative events (from calungan to wayang and also lènggèr, ebeg and so forth). 


\section{Ricik Ricik in The Vocal Style of Banyumas}

Ricik Ricik is maybe the most well-known and widespread piece of Banyumas tradition. It is often adopted also in other areas, from Yogyakarta to Surabaya, thanks to its playful character and adaptability to many performative contexts. But only in Banyumas its vocal elaboration assumes the complexity which is undetected in other areas. The balungan (skeleton melody) of Ricik Ricik consists of 16 beats, divided into 4 gatra (groups of 4 notes) and marked by 4 kenongan (kenong strikes, signaling strong cadential notes): ${ }^{2}$

$\begin{array}{lllllllll}\text { Balungan: } & \text { i } & 6 & 3 & 2 & 5 & 3 & 2 & \text { (1) }\end{array}$

$\begin{array}{llllllll}2 & 1 & 5 & 3 & 5 & 6 & \text { i } 6\end{array}$

Figure 8. Kepatihan (cyphered notation) of the balungan melody of Ricik Ricik in slendro sanga.

The elaboration of this piece in the Banyumas style combines diverse sections, including: koor or lagu, selingan, parikan and sindhenan.

I recorded and transcribed a version of Ricik Ricik in Pegalongan village on December the $12^{\text {th }}, 2017$, during a rehearsal of the Sanggar Seni Budaya Ngudi Luwesing Salira calung group. The elaboration of the skeleton melody was articulated in different parts. The first part consisted in an instrumental introduction in irama lancar (fast tempo). The second section included a passage to irama I and a koor (female and male unison singing) as following:

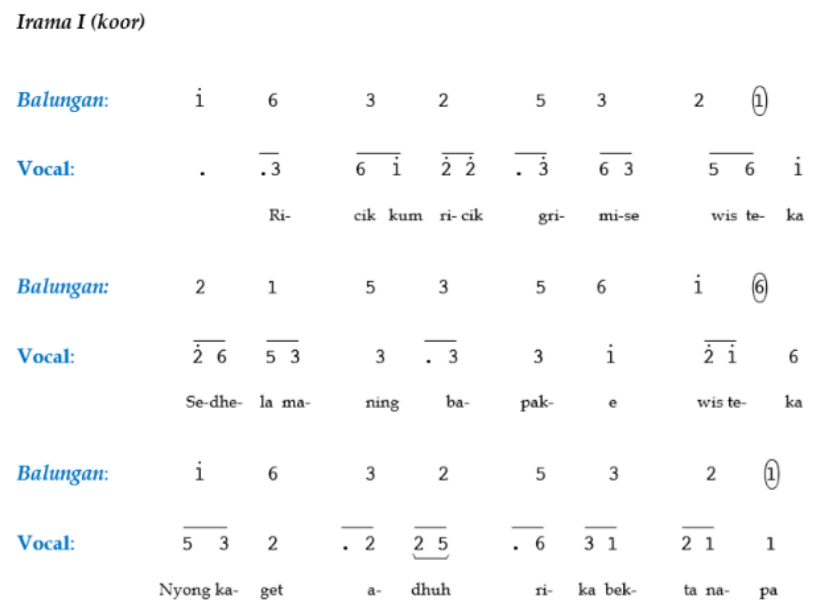

$\begin{array}{lccccccccc}\text { Balungan: } & 2 & 1 & 5 & 3 & 5 & 6 & \mathrm{i} & 6 \\ \text { Vocal: } & \cdot & \overline{.5} & 6 & \overline{.5} & \overline{31} & \overline{13} & 2 & \overline{.1} & 6 \\ & & \text { Bung-kus } & \text { pe- thak ni- } & \text { ku i- } & \text { si } & & \text { na- } & \text { pa }\end{array}$

Figure 9. Music transcription of the koor or lagu section of Ricik Ricik in slendro sanga.

According to Ibu Muriah, this passage was not part of the original version (khas banyumasan) but it has been added by Ki Nartosabdo (Petersen 2001; Meloni 2019), so that it is often referred to as semarangan (in the style of Semarang), though lyrics are in ngapak (Banyumas local language). This version of Ricik Rick (the title meaning "small rain") is the most common to hear in Banyumas neighboring areas like Yogyakarta and Surakarta. In addition, other choral versions can be found according to the context. New koor parts are continuously composed by teachers and musicians to be included in Ricik Ricik elaboration. For example, another famous version, taught in ISI Surakrta, is the one composed by Pak Rasito (Kartawi 2016).

Another possible vocal elaboration of the skeleton melody is the sauran or selingan. It is also acknowledged as a later addition from the original version:

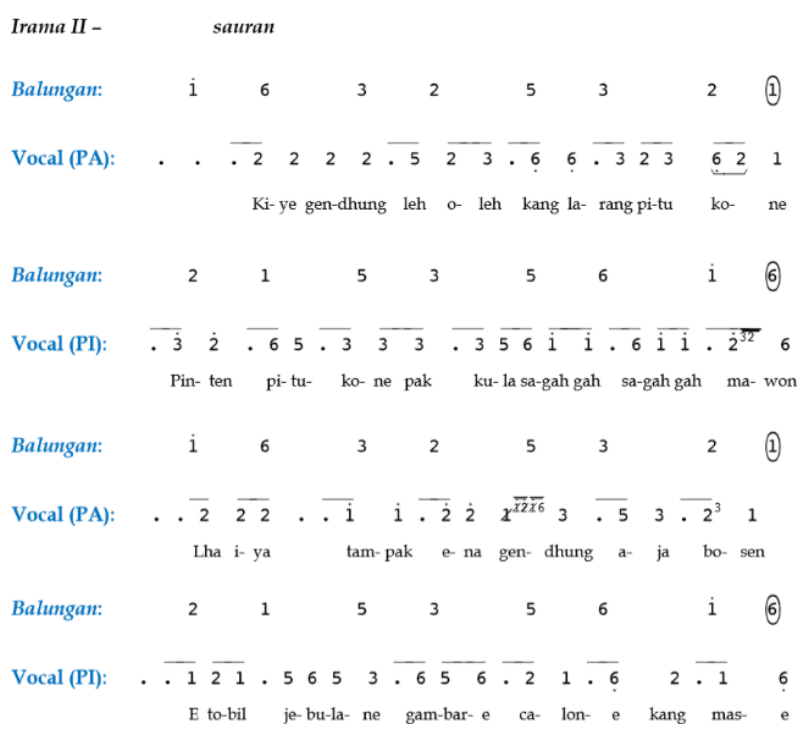

Figure 10. Music transcription of the sauran or selingan section of Ricik Ricik in slendro sanga.

This section, usually executed in the irama II (slower tempo) can be performed in unison or by a soloist, usually alternating male and female voices in an answer/question modality. ${ }^{3}$ The two parts

\footnotetext{
The transcriptions have been realized by the author using KepatihanPro software.

$3 \quad$ PA $($ putra $=$ male $)$ and PI (putri $=$ female $)$ in the transcription.
} 
differ in the music register: the male part is lower than the female part. The use of pathet miring (a modulation of slendro sanga on pelog scale, Becker 1984: 348-349) is evident in the third line of the transcription (Picture 10). It is another strong hallmark of Banyumas style, probably born out of the necessity to overcome the limits imposed by the adoption of only one scale system. The sauran section is a sort of vocal game and it can be also performed by a solo sindhen alternated with a chorus or a sindhen and a penggerong (male vocalist). Differently from other central Javanese styles, in Banyumas vocal practice is not rare that female singers perform what is usually restricted to male singers (gerongan, senggakan, alok etc.). One of the most interesting cases is the mantra Kajune purwa sejati, used in shadow puppet theatre for introducing the comic interlude. In wayang kulit, mantras are usually carried out almost exclusively by the puppeteer. However, this specific mantra in Banyumas style is often sung by a female singer.

Another section, which still results to be a later addition but is closer to the Banyumas original style, is the following:

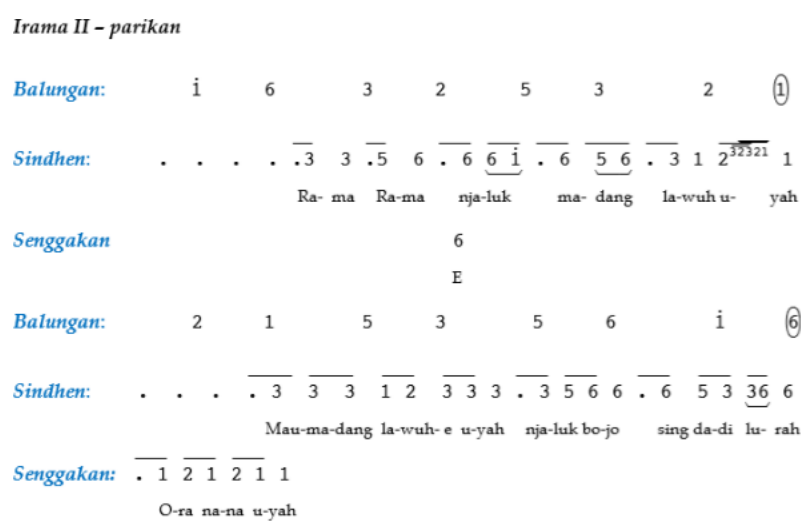

Figure 11. Music transcription of the modern-style parikan of Ricik Ricik in slendro sanga.

The lyrics of this section resemble the parikan genre, meaning improvised riddles in a free meter, which is the specificity of the old-time banyumasan singing. Though, here, parikan are composed in a modern style and are articulated in an answer/question standard formula, intersected with senggakan ("filling" phrases, similar to the "counter melody" practice in Western Art Singing). Senggakan is another vocal form typical of Banyumas, though now used also in other central
Javanese styles. Senggakan is a fundamental element in Banyumas music since: "Good Banyumas vocal performance is generally described as ramè, a term indicating lots of activity, "busy" or "noisy" in a positive sense" (Sutton 1991: 93). It can be said that senggakan, together with parikan, are the very essence of Banyumas vocal practice. The original practice of parikan consists of the vocal elaboration of melodic patterns on free-metered short phrases ending in a rhyme. Presumably, they are in close relation with (or probably derived from) pantun, poetic meters typical of Sundanese region (Van Zanten 1993). The content is often humoristic and provocatory, with a high potential of interaction and entertainment. Parikan are usually improvised in an extemporary and spontaneous way, with the aim to provoke and entertain the audience, even though some parikan became well-known and now they constitute a sort of stable corpus, handed down from expert sindhen (like Mak Narsih) to their apprentices.

Nowadays, it is not rare to find parikan riddles also in Yogyanaese or Solonese music, especially in light pieces with a humorous purpose, like during wayang kulit comic interludes (Meloni 2021). Parikan constituted the most common repertoire of the ancient singer-dancers, before sindhen practice were introduced in Banyumas area together with the adoption of other textual forms like central Javanese wangsalan. The main difference between central Javanese sindhenan and sindhenan banyumasan lies precisely in the lyrics' typology. While parikan is specific to Banyumas area, wangsalan (riddles in poetic form deriving from court literature) are typical of Yogyanese and Solonese styles. However, over the decades, the influence of central Javanese practice gave birth to a new form called wangsalan banyumasan, that we can also find in Ricik Ricik elaboration, as follows:

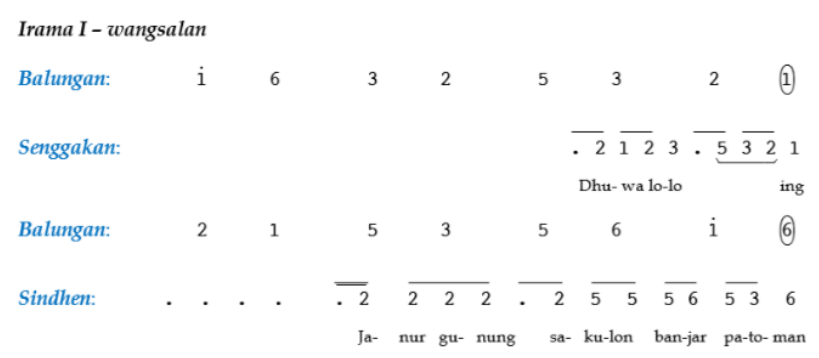


Balungan:

Sindhen: i 6$$
\text { . }
$$

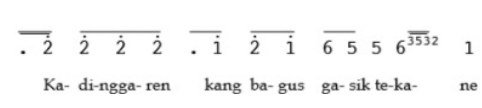

Figure 12. Music transcription of the wangsalan banyumasan section of Ricik Ricik in slendro sanga.

The difference between central Javanese wangsalan and wangsalan banyumasan dwells mainly in the origin (court literature vs extemporary improvisation) and in the content. Wangsalan banyumasan metrical structure remains the same of the central Javanese wangsalan: a total of 24 syllables divided in a cangkriman ("question") and a batangan ("answer") of 12 syllables each, furtherly divisible in groups of 4 and 8 syllables, which makes sindhen able to improvise cengkok (melodic formulas) on the stronger cadenzas of the skeleton melody. However, while central Javanese riddles originates from court literature and are written in a mixture of old and modern Javanese (often with words in kawi, derived from Sanskrit), wangsalan banyumasan are in ngapak language and they are based on common life experience or local folklore, rather than myths and legends of the glorious Javanese kingdoms. The wangsalan question which appear in this transcription (picture 12) recites: "Janur gunung sakulon banjar patoman". Meaning: "The coconut tree growing in West Banjar Patoman [locality]". The answer is: "Kadinggaren, wong bagus gasik tekane". Meaning: "The name of the tree is kadinggaren, a good man poses the question". The words gasik tekane recalls the word "Tasik", a specific locality in which the tree grows in West Banjar Patoman, so that it makes easier to identify the tree type mentioned in the question.

Wangsalan can be sung in alternation with isen isen (filling non-sense formulas) or senggakan. Dhuwa lolo (which appear in the first line of the transcription) is a common Banyumas formula, often used with "filling" purpose (like a senggakan). It is another strong trait, very specific (khas) of banyumasan style and it can be heard in many other pieces of Banyumas repertoire, while is uncommon in other regional variants like in Yogykarta or Surakarta styles.

Another interesting issue to notice concerns the many irama transitions (mainly irama I and irama II, but it's not uncommon to listen to versions extending until the irama III) which is unusual in a lancaran form, according to the central Javanese musical practice.

In conclusion of this analysis, it can be said that the main features of music elaboration in Banyumas are: a majority of pieces in lancaran form; a great flexibility in the music elaboration even on short-cycled ( 8 or 16 beat per gongan) structures; a great variety in the vocal elaboration, including: choral or unison piece (koor or lagu), alternate singing between male and female parts (sauran or selingan), solo sindhen in central Javanese style and spontaneous improvisation of free-metered riddles (parikan) with "fillings" (senggakan) in order to make the piece "noisy" or "busy". Voice is thence a very important element in Banyumas music, especially female voice, which is often described as sindhenan banyumasan but, as we have seen in the previous paragraphs, it includes miscellaneous vocal traditions.

\section{Specificities of sindhenan banyumasan}

To sum up the specificities of the female singing in Banyumas style, from what emerged from the analysis and the discussion, is it possible to say that the main features are, as listed below:

1. The singing is mainly articulated on short-cycle music pieces (lancaran). Therefore, the cengkok (vocal patterns) results less ornamented and articulated than central Javanese ones. On the other hand, vocal elaboration includes multifold variants other than sindhen solo (or srambahan) and it often includes parts that in central Javanese practice are associated with penggerong (male singers).

2. Specific lyrics of banyumasan singing resulted to be either parikan and senggakan, freemetered phrases sung in a spontaneous and humoristic attitude, though central Javanese texts (wangsalan) and modern composition (koor or lagu) are increasingly becoming an integrated part of Banyumas vocal music.

3. The singing is often accompanied by calung (bamboo instrumental ensemble) instead of gamelan (bronze music ensemble). This element might contribute to the diversification of the 
sindhen voice quality, which in central Java results "sharper" and more crystalline (as it should resonate on higher frequencies to be hearable without microphones).

4. The music knowledge is mainly handed down via oral transmission (or alami, "natural" way) with a preference for direct practice (or the indang, "gift", in the past) though classes of Banyumas music and singing are available in some central Javanese academies, like ISI Surakarta.

5. Sindhen is still often associated to singer-dancer (of lènggèr genre) due to the common origins and the present-days coexistence, though it has undergone many changes after New Order. For this reason, sindhen staginess in Banyumas results to be often more playful and uninhibited if compared to central Java, whose sindhen are more strictly linked to court aesthetics and observe a rigid ethic.

\section{Conclusion}

Sindhenan banyumasan or female traditional singing in the style of Banyumas reveals to be not only a peculiar variant of the central Javanese vocal practice, with differences and common traits, but an interesting vocal tradition itself. Its peculiarity is often labelled with the adjective kasar, which according to central Javanese aesthetics means "rough" and is the opposite of halus ("refined") (Anderson 1972). This aesthetic categorization is often motivated looking at some of the main features of Banyumas music. While in central Java we find long and complex gendhing (musical pieces) in Banyumas we mainly find short-cycled form (lancaran). While central Javanese lyrics, wangsalan, constitute a prestigious heritance of high court literature, parikan and wangsalan banyumasan express the open and jovial spirit of Banyumas people. ${ }^{4}$

Notwithstanding, I argue that rather than an example of the dualism existing in court aesthetics, Banyumas vocal practice is more likely the testimony of a musical and cultural pluralism embedded in the Javanese territory as well as in the whole Indonesian archipelago. Sindhenan banyumasan is only a small example of how local traditions can merge together, be transformed in time and undergo processes of transformation which resemble the epochal changes. It is also an example of how living traditions are constantly innovated and in dialogue with each other, and how "unity" is more in "similarity" and "pluralism" rather than in "diversity".

\section{Acknowledgements}

I would like to express my deep gratitude to La Sapienza University and ISI Yogyakarta for having supported my research. A special thanks goes to the marvelous people of Sanggar Seni Budaya Ngudi Luwesing Salira in Pegalongan village who offered me warm hospitality and disclosed to me their musical and cultural knowledge. A special thanks to Ibu Narsihati and Pak Suchedi to have guided me in the journey across sindhenan banyumasan like some parents guide their child throughout the journey of a new life. A special thanks goes also to Ibu Muriah and Pak Darno, teachers in ISI Surakarta, who let me join their classes and dedicated me precious time for answering my questions. I hope this will be only a first stone laid for future collaborations and cultural exchanges.

\section{References}

Anderson, B. (1972). Java in a Time of Revolution. Ithaca: Cornell University Press.

Baier R. \& Manuel, P. (1986). Jaipongan: Indigenous Popular Music in West Java. Asian Music, Vol. 38 (No. 1), 91-110.

Bartz G. \& Cooley T. J. (Eds.). (1997). Shadows in The Field: New Perspectives for Fieldwork in Ethnomusicology. New York: Oxford University Press.

Becker, J. (1984). Michigan Papers on South and Southeast Asia. Ann Arbor.

Budiarti, M. (2008). Sekilas Tentang Sindhenan Banyumasan. Kêtêg. Jurnal Pengetahuan,

4 Like their dialect, in which the vowel "a" in final position of a word is not turned in "o" like it happens in central Javanese dialect, this proving an attitude of openness and frontality, according to Herusatoto (2008). 
Pemikirkan dan Kajian Tentang Bunyi, Vol. 8 (No. 1), 1-19.

Budiarti, M. (2013). Konsep Kepesindhenan dan Elemen Elemen Dasarnya. Harmonia, Vol. 13 (No. 2).

Cooper, N. (2000). Singing and Silences: Transformations of Power Through Javanese Seduction Scenarios. American Ethnologist, Vol. 27 (No. 3), 609 - 644.

Dean, R. T. \& Smith, H. (Eds.). (2009). Practiceled Research, Research-led Practice in the Creative Arts. Research Methods for the Arts and Humanities. Edinburgh University Press.

Di Bernardi, V. (1995). Introduzione allo Studio del Teatro Indonesiano: Giava e Bali. Firenze: La Casa Usher.

Herusatoto, B. (2008). Banyumas: Sejarah, Budaya, Bahasa dan Watak. Surakarta: LkiS.

Hood, M. (1960). The Challenge of Bi-Musicality. Ethnomusicology Vol. 4 (No. 2), 55-59.

Hughes-Freeland, F. (1997). Art and Politics: from Javanese Court Dance to Indonesian Art. The Journal of the Royal Anthropological Institute. Vol. 3 (No. 3), 473-495.

Kartawi, D. (2016). Gendhing-gendhing Banyumas. Sindenan, Senggakan, Balungan. ISI Surakarta.

Lysloff, R. (1990). Non- Puppets and NonGamelan: Wayang Parody in Banyumas. Ethnomusicology Vol. 34 (No. 1), 19-35.

Lysloff, R. (1992). Innovation and Tradition: Calung Music in Banyumas (West and Central Java). Festival of Indonesia Conference Summaries, in Perlman, M. and Yampolski, P. (edited by). New York: The Festival of Indonesia Foundation.

Lysloff, R. (2001). Rural Javanese Tradition and Erotic Subversion: Female Dance Performance in Banyumas (Central Java). Asian Music Vol. 33 (No. 1), 1-24.

Lockard, C. A. (1998) Dance of Life: Popular Music and Politics in Southeast Asia. University of Hawaii Press.

Meloni, I. (2019). Ki Narthosabdho's Legacy and the Effects on Yogyanese Wayang Kulit. Music, Individual and Contexts: Dialectical Interaction. Amendola N., Cosentino A., Sciommeri G. (edited by). Roma: Società
Editrice di Musicologia, Universitalia. Meloni, I. (2021). "Show-Time" for the Sindhen, or the Time of Limbukan: New Performing Practices and Musical Repertoires in the Comic Interlude of Yogyanese Wayang Kulit. Giovanni Giuriati (edited by), Patterns of Change in the Traditional Music of Southeast Asia, Intersezioni Musicali BOOK IM10. Udine: Nota.

Penny, J. (2014). Reflections on Practice-led Research Methods and their Application in Music Performance Research. Malaysian Journal of Music Vol. 3(No. 2), 84-92.

Petersen, N. (2001). Lakon Karangan: The Legacy of Ki Nartosabdho in Banyumas, Central Java. Asian Theatre Journal Vol. 18 (No. 1), 105112.

Rahayu, S. (2017). Garap Sindhenan Surabayan Jawa Timur. Surakarta: Penerbit Press.

Rice, T. (2014). Ethnomusicology. A very short introduction. Oxford University Press.

Saedipun, A. (2015). Perkembangan dan Perubahan Tepak Kendang Jaipongan Suwanda dalam Masyarakat Urban. Journal of Urban Society's Arts. Vol. 2 (No. 1), 9-17.

Solís, T. (Ed). (2004). Performing Ethnomusicology: Teaching and Representation in World Music Ensembles. University of California Press.

Surtihadi, R. M. (2014). Instrumen Musik Barat dan Gamelan Jawa dalam Iringan Tari Keraton Yogyakarta. Journal of Urban Society's Arts. Vol. 1 (No. 1), 27-43.

Sutton, A. R. (1984). Who is the Pesindhen? Notes on the Female Singing Tradition in Java. Indonesia Vol. 31, 119 - 133.

Sutton, A. R. (1985). Musical Pluralism in Java: Three Local Traditions. Ethnomusicology Vol. 29 (No. 1), 56 - 85.

Sutton, A. R. (1986). The Crystallization of a Marginal Tradition: Music in Banyumas West Central Java. Yearbook for Traditional Music Vol. 18 (115-132).

Sutton, A. R. (1991). Traditions of Gamelan Music in Java: Musical Pluralism and Regional Identity. Cambridge University Press.

Tohari, A. (2012). The Dancer. Indonesia: The Lontar Foundation. 
Van Zanten, V. (1989). Sundanese Music in the Cianjuran Style: Anthropological and Musicological Aspects of Tembang Sunda. Leiden: Floris Publications.

Van Zanten, V. (1993). Sung Epic Narrative and Lyrical Song: Carita Pantun and Tembang Sunda. Performance in Java and Bali. Arps B. (edited by). London: SOAS.

Vickers, A. (2005). A History of Modern Indonesia. Cambridge University Press.

Walton, S. (1987). Mode in Javanese Music. Athens: Ohio University.

Walton, S. (1996). Heavenly Nymphs and Heartly Delights: Javanese Female Singers, their Music and their Lives. The University of Michigan.

Weintraub, A. (2004). The Crisis of the Sindhen: Gender, Politics and Memory in the
Performing Arts of West Java, 1959 - 1964.

Indonesia (No. 77, April), 57-58.

Yampolski, P. (1991). Music of Indonesia, Vol. 1. Songs Before Dawn: Gandrung Banyuwangi (CD booklet). Smithsonian Folkways Recordings.

Yusmanto. (2006). Calung (Kajian Identitas Kebudayaan Banyumas). ISI Surakarta.

\section{Informants}

Narisihati. 2017. Maestro lènggèr and sindhen of Pegalongan village (Banyumas regency).

Suchedi. 2017. Musician and teacher in SMA Pegalongan (Banyumas Regency).

Muriah Budiarti. 2017. Sindhen and docent at ISI Surakarta. 